INTERIM REPORT

ORNL/Sub/87-00184/06

\title{
MEASUREMENT OF GAS TRANSPORT PROPERTIES FOR CHEMICAL VAPOR INFILTRATION
}

\author{
T. L. Starr and N. Hablutzel \\ PECENVD \\ JAN 291027 \\ December 1996

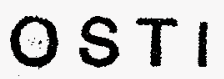 \\ Report prepared by \\ School of Materials Science and Engineering \\ Georgia Institute of Technology \\ Atlanta, Georgia 30332-0245 \\ under

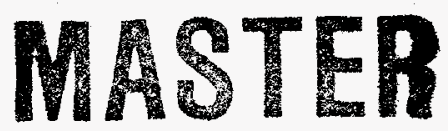 \\ Sub-contract 19X-00184C \\ for
}

OAK RIDGE NATIONAL LABORATORY

Oak Ridge, Tennessee 37831

managed by

LOCKHEED MARTIN ENERGY RESEARCH CORP.

for the

U.S. DEPARTMENT OF ENERGY

under Contract No. DE-AC05-96OR22464

DISTPIDITAM OF TIS DOCIMENT IS UNLIMITEO 
This report has been reproduced directly from the best available copy.

Available to DOE and DOE contractors from the Office of Scientific and Technical Information, P.O. Box 62, Oak Ridge, TN 37831; prices available from (423) 576-8401.

Available to the public from the National Technical Information Service, U.S. Department of Commerce, 5285 Port Royal Rd., Springfield, VA 22161.

This report was prepared as an account of work sponsored by an agency of the United States Government. Neither the United States Government nor any agency thereof, nor any of their employees, makes any warranty, expressed or implied, or assumes any legal liability or responsibility for the accuracy, completeness, or usefulness of any information, apparatus, product, or process disclosed, or represents that its use would not infringe privately owned rights. Reference herein to any specific commercial product, process, or service by trade name, trademark, manufacturer, or otherwise, does not necessarily constitute or imply its endorsement, recommendation, or favoring by the United States Government or any agency thereof. The views and opinions of authors expressed herein do not necessarily state or reflect those of the United States Government or, any agency thereof. 


\section{DISCLAIMER}

Portions of this document may be illegible in electronic image products. Images are produced from the best available original document. 


\title{
MEASUREMENT OF GAS TRANSPORT PROPERTIES FOR CHEMICAL VAPOR INFLTRATION
}

\author{
T. L. Starr and N. Hablultzel
}

December 1996

Research Sponsored by the U. S. Department of Energy, Fossil Energy Advanced Research and Technology Development Materials Program

\author{
Report prepared by \\ School of Materials Science and Engineering \\ Georgia Institute of Technology \\ Atlanta, Georgia 30332-0245 \\ under \\ Sub-contract 19X-00184C \\ for \\ OAK RIDGE NATIONAL LABORATORY \\ Oak Ridge, Tennessee 37831 \\ managed by \\ LOCKHEED MARTIN ENERGY RESEARCH CORP. \\ for the \\ U. S. Department of Energy \\ under Contract No. DE-AC05-960R22464
}




\section{ABSTRACT}

Gas transport by pressure-driven permeation or by concentration-driven diffusion is a key step in the chemical vapor infiltration (CVI) process. This report describes methods for measuring these properties for CVI preforms and partially infiltrated composites. Results are presented for Nicalon fiber cloth layup preforms and composites, Nextel fiber braid preforms and composites, and a Nicalon fiber 3-D weave composite.

The permeability of Nicalon cloth layup preforms depends strongly on packing density over the range of 29 to 40 volume percent, but only weakly on the orientation of alternating cloth layers. The specimen-to-specimen variation is high (standard deviation of $20 \%$ ) reflecting the statistical nature of the interlayer separation and alignment. This variability also affects the results for the partially densified specimens where the permeability values for specimens of similar density can be very different.

The permeability of Nextel braid preforms depends on the thread count and weight for cloths with similar construction and packing density. The gas permeability of the finer weave (16 tows/inch) is approximately half that of the coarser weave ( 9 tows/inch). Results are reported for a small number of infiltrated composites with Nextel fiber reinforcement.

Attempts to mount a specimen of Nicalon fiber 3-D weave preform were unsuccessful. Results for a small number of composite specimens with 3-D weave reinforcement are reported.

The experimental results are consistent with a percolating network model for gas transport in CVI preforms and composites. This model predicts inherent variability in local pore characteristics and transport properties, and consequentially, in local densification behavior during processing. Better understanding of this phenomenon may lead to preform or process variations that produce gas-tight composite materials.

Research sponsored by the U.S. Department of Energy, Fossil Energy Advanced Research and Technology Development Materials Program, DOE/FE AA 151010 0, Work Breakdown Structure Element GT-1 


\section{INTRODUCTION}

In the chemical vapor infiltration (CVI) process for fabrication of ceramic matrix composites (CMC's), a critical step is transport of gas phase reactant species to the interior of the fiber preform. Whether pressure-driven (forced-flow CVI) or concentration-driven (isobaric CVI) this transport depends on the microstructure of the porous, partially densified composite and controls the rate and uniformity of infiltration. Direct experimental measurement of this property is important for understanding the role of microstructure on processing and for testing models of gas transport.

Studies of gas (and more, generally, fluid) transport through porous media and models for this transport have been reported in the literature over many years and in many technical areas. Such transport is fundamental in fields as diverse as gas filtration, heterogeneous catalysis, pollutant migration, resin transfer molding of polymer composites and coal gasification. While some of this work is applicable to mass transport during CVI processing, much is not, due to the special characteristics of this process for fabrication of dense CMC's. For example, while measurements and models for gas permeability of fibrous filters are well worked out ${ }^{1}$, these are limited to materials with randomly oriented fibers at low volume fraction (less than $10 \%$ vol). In contrast, for CVI the fiber preform usually has fibers arranged in an anisotropic, bimodal pattern at a volume fraction near $40 \%$. In addition, the evolution of the transport properties of this compact as the density increases is a critical factor in the process.

A small number of measurements of gas permeability of partially infiltrated composites have been reported previously ${ }^{2}$. These exhibit the general anisotropy and density dependence expected for a cloth layup reinforcement pattern, however, no measurements were made with preforms or with other reinforcement architectures. Also, mass diffusivity was not measured. More recently, a model for gas transport in CVI preforms and composites has been proposed ${ }^{3}$. Describing the porosity as a percolating network, this model predicts the dependence of transport on density during CVI infiltration. Although a reasonable choice of model parameters yields good match to the experimental measurements, a general understanding of the relationship between model parameters and preform structure is lacking. This is a critical link toward obtaining a truly predictive model.

A necessary step in gaining this understanding is measurements of gas transport properties of a wider array of fiber architectures and their composites. We describe a method for measuring 
the gas permeability and mass diffusivity of fiber preforms and partially dense composites. Although both transport properties are related to the pore microstructure, they are driven, respectively, by pressure and by concentration differences across the porous medium, and depend on different characteristics of the pore structure. Results are presented for Nicalon fiber cloth layup preforms and composites, Nextel fiber braid preforms and composites, and a Nicalon fiber 3-D weave composite.

\section{EXPERIMENT}

Gas permeability and mass diffusivity are measured on small material specimens using a single apparatus. Specimens are either fiber preforms or partially infiltrated composites with fiber reinforcement.

\section{Measurement Apparatus and Material Specimen}

Gas permeability and mass diffusivity are measured using the apparatus shown schematically and photographically in Figure 1. The cylindrical specimen holder has an inside diameter of $2.54 \mathrm{~cm}$ and accepts a disk-shaped specimen up to $3 \mathrm{~cm}$ thick (although specimens usually are considerably thinner than this). Rubber o-rings seal the top and bottom surfaces of the specimen. The bottom of the specimen holder is connected through a mass flowmeter (MKS Instruments, Andover, MA) to a regulated source of helium. Either of two flow meters $(0-20$ and 0-200 sccm) can be used. The bottom chamber also is connected through a valve to the "carrier" inlet of a thermal conductivity detector (TCD) of the type used for gas chromatography (SRI Instruments, Torrance, CA). This detector is designed to produce a millivolt response proportional to the concentration of methane in a helium gas stream. The "reference" inlet of the TCD is connected directly to the helium source. The top of the specimen holder is connected to the atmosphere through a rotameter (not shown) and to a regulated source of a helium-methane mixture. The two sides of a differential pressure (DP) gauge (MKS Instruments) are connected above and below the specimen. The apparatus includes two different DP gauges ( $0-10$ and 0-200 torr). A 4-port valve can be switched to connect together the two ends of the DP gauge to allow checking of the gauge zero point reading. An absolute pressure gauge (MKS Instruments) also is connected to the bottom of the chamber. 


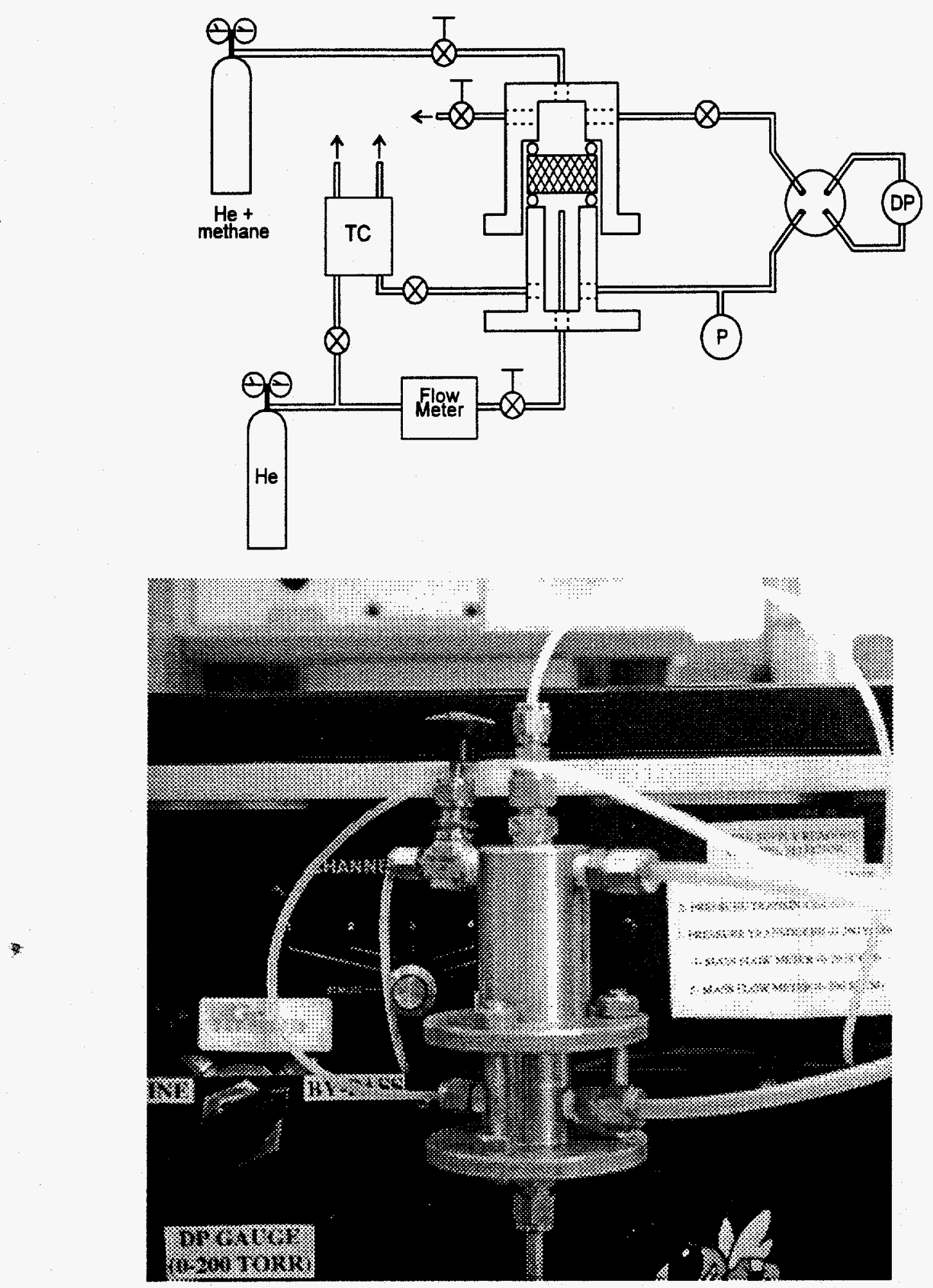

Figure 1. Schematic (top) and photographic (bottom) views of apparatus for measuring gas permeability and mass diffusivity. 
The choice of specimen mounting method depends on the amount and type of material to be tested. Examples of these specimens are shown in Figure 2. In all cases the apparent density of each specimen is deterimined prior to mounting by measuring its mass and dimensions.

A full-size disk specimen is machined to fit closely within the $2.54 \mathrm{~cm}$ ID of the specimen holder and the outer radius of the disk is sealed using a viscous, fast-setting epoxy cement. The top and bottom surfaces of these specimens must be smooth, flat and parallel to allow good seating with the o-ring seals. This is accomplished by machining the material or by cementing flat, aluminum rings to the top and bottom surfaces. With this type of specimen the material must be rigid enough to allow application of sealing force without deforming the material.

Smaller material specimens are prepared by mounting them within a thick aluminum ring using the epoxy cement. Generally these specimens are cored from a larger piece of material using a diamond core drill, producing a disk-shaped specimen. Other shapes also can be mounted in this manner as long as they have two parallel faces.

A variation of this latter mounting method is used for measurement of cloth layup preform properties. In this case, individual disks of cloth are cut to fit closely inside the aluminum ring. A specified number of layers are stacked with prescribed orientation between layers. This "preform" specimen is held in place by two perforated aluminum lids that are held in place with cement or with screws.

With these specimens it is important to verify that the mounting method is successful in limiting gas transport to that through the specimen. This is checked in two ways. First, the specimen is mounted in the chamber using an upper section that is open on the top. A thin layer of water is placed on the specimen and the bottom chamber is pressurized to induce flow. If properly mounted, the resulting bubbles will originate from the face of the specimen rather than the edges. The second check is to assure that flow does not leak past the o-ring seals. The specimen is mounted in the normal way and all valves connected to the upper chamber are closed. Gas is flowed into the bottom chamber until pressurized to approximately $150 \%$ ambient. With all valves closed, the pressure should be stable over a period of several minutes. 


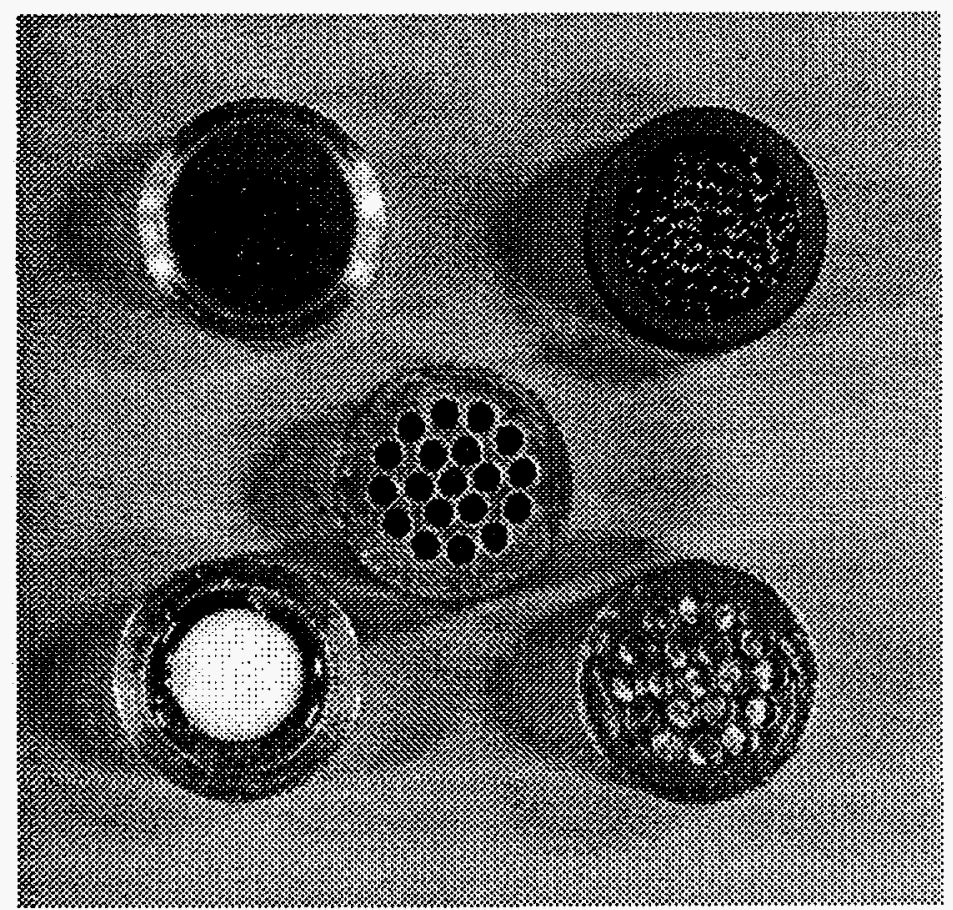

Figure 2. Material specimens can be full size or mounted in aluminum rings.

\section{Gas Permeability Measurements}

For permeability measurements, only valves v1-v3 are open. The helium gas flow rate is adjusted using the needle valve $\mathrm{vl}$ and the differential pressure across the specimen is recorded for each flow level. The gas permeability is calculated from a linear fit to the flow vs. pressure data, the specimen dimensions and the viscosity of helium. A typical plot of measured data and the resulting fit is shown in Figure 3. The estimated standard error for these measurements, based on the goodness-of-fit, is often as low as $1-2 \%$ of the permeability value.

The gas permeability $(\mathrm{K})$ is calculated from the slope of the "least-squares" fit to the experimental data using;

$$
K=\frac{d F}{d P} \frac{\mu L}{A}
$$

where $\mu$ is the gas viscosity (194.1 $\mu$ Poise for helium $\left.{ }^{4}\right), \mathrm{L}$ is the specimen thickness, $\mathrm{A}$ is the specimen face area and $\mathrm{dF} / \mathrm{dP}$ is the slope. The resulting value is conveniently expressed in units of darcy ( 1 darcy $=10^{-8} \mathrm{~cm}^{2}$ ). 


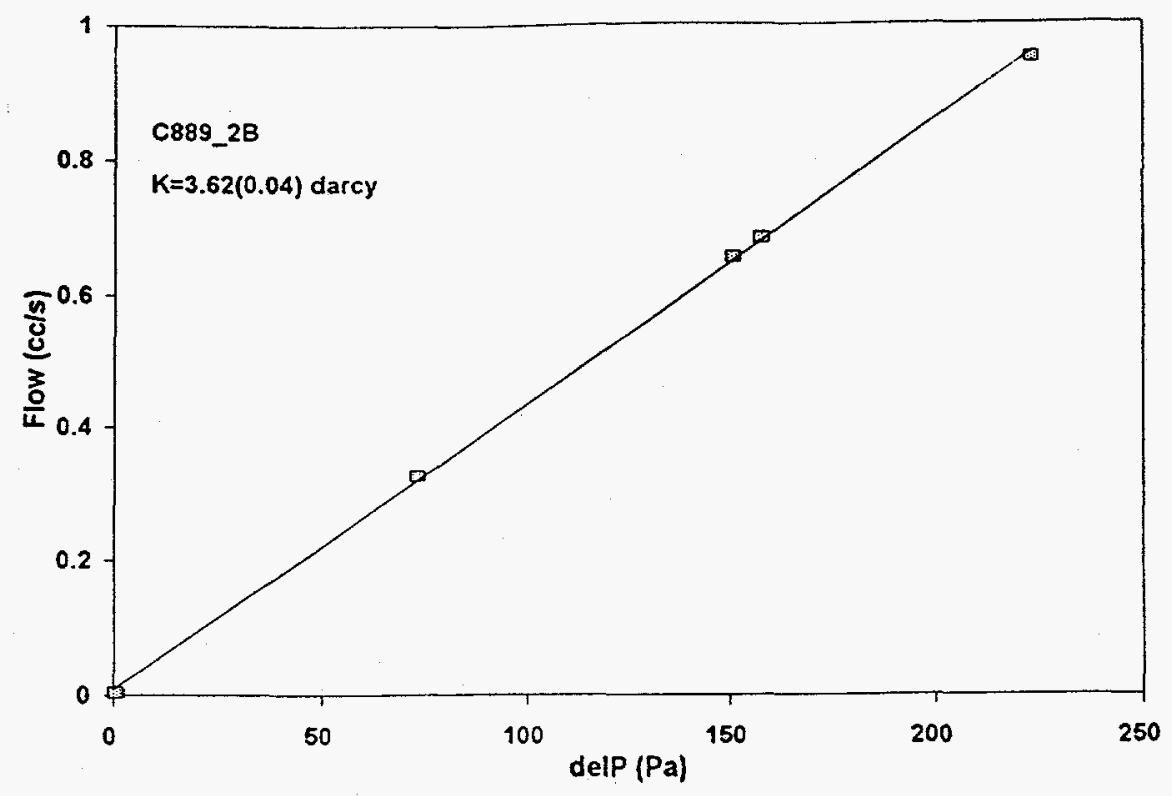

Figure 3. Gas permeability is calculated from linear fit to measured flow versus differential pressure.

\section{Mass Diffusivity Measurements}

For mass diffusivity, valves v4-v6 are opened producing flow of a helium-10\% methane mixture across the top face of the specimen and of pure helium across the bottom face. Using the 0-10 torr DP gauge, the differential pressure across the specimen is adjusted over a range of values near zero. For a particular setting, the amount methane passing through the specimen is detected using the TCD. Near zero differential pressure the concentration of methane through the detector depends on both convection and diffusion, and is proportional to the expression,

$$
U\left(1+\frac{1}{\exp \left(P_{e}\right)-1}\right)
$$

where $U$ is the linear velocity of the gas through the specimen which is calculated from the gas permeability and the pressure difference, $P_{e}$ is the Peclet number UL/D, $L$ is the thickness of the specimen and $D$ is the mass diffusivity $\left(\mathrm{cm}^{2} / \mathrm{s}\right)$. Fitting this curve to the measured data gives the 
mass diffusivity (Figure 4). This value is converted to a dimensionless diffusion factor by dividing by the handbook value of the free space diffusion coefficient for methane in helium ${ }^{5}$, $0.748 \mathrm{~cm}^{2} / \mathrm{s}$. This diffusion factor relates to the amount and tortuosity of the open porosity in the specimen.

Note that by using the expression above and the measured value of the gas permeability it is not necessary to calibrate the response of the TCD relative to an absolute value of the methane concentration. It is critical, however, that the response of the detector is measured relative to a well-determined "baseline" for $0 \%$ methane. This "zero point" calibration is performed prior to and after each series of measurements by flowing pure helium through the detector. This baseline response was found to be somewhat dependent on flow rate through the detector and each measurement was "flow-corrected" to assure high accuracy.

Also critical is determination of the zero point value for the differential pressure. This is determined for every measurement by briefly switching the valve to bring the ends of the DP gauge together and recording the gauge output. This procedure corrects for small "drift" and pressure dependence of the DP gauge.

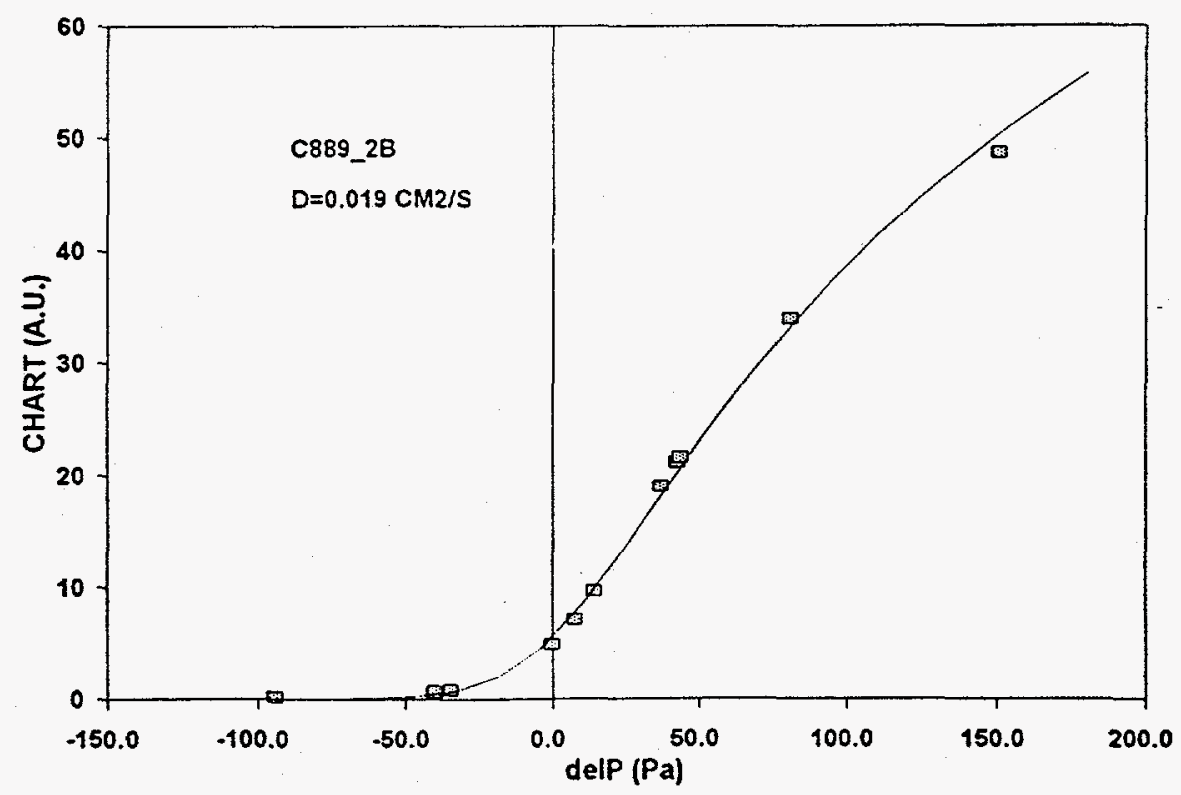

Figure 4. Mass diffusivity is calculated from fit to measured methane concentration versus pressure differential across specimen. 
A number of materials have been characterized using the methods above. These include preforms and partially densified CVI composites with fiber reinforcement consisting of Nicalon fiber cloth layup, Nextel fiber braid and Nicalon fiber 3-D weave.

\section{Nicalon Fiber Cloth Layup Composite}

CVI composites are commonly fabricated using Nicalon fiber (Nippon Carbon, Tokyo, Japan) in a plain weave cloth layup reinforcement architecture. The Nicalon cloth layup composite gas permeability and diffusion factors are summarized in Table 1. Preform permeability results derive from plain weave cloth consisting of tows with 500 filaments and woven at 16 tows/inch. For the test specimens 24, 29 and 33 layers are stacked and compressed to a thickness of $0.90 \mathrm{~cm}$, giving 29,35 and 40 volume percent fiber, based on a fiber density of $2.55 \mathrm{~g} / \mathrm{cm}^{3}$. Each value is the average of measurements on 15-16 different specimens. The standard deviation for multiple specimens of the same configuration range from $13-20 \%$ of the mean permeability value, although repeated measurements on a single specimen vary less than 5\%. Plotting these results (Figure 5) shows a strong relationship between permeability and fiber volume fraction, but no significant difference with the different orientations.

Diffusion factors in Table 1 for Nicalon cloth layup specimens are averages of two separate measurements on a single specimen for each combination of orientation and packing density. Again, the values vary with volume fraction but show no significant dependence on orientation.

New permeability and diffusion factor measurements for a number of CVI infiltrated composites are shown in Table 1. All composites were fabricated from $0 / 30 / 60$ cloth layup preforms with $40 \%$ fiber. All specimens were cut so as to measure transport perpedicular to the cloth layers. The permeability measurements, along with measurements reported previously ${ }^{2}$, are plotted in Figure 6. 
Table 1. Measurements of permeability and mass diffusivity for Nicalon fiber cloth layup preforms and composites.

\begin{tabular}{|c|c|c|c|c|c|}
\hline \multicolumn{2}{|r|}{ specimen } & \multicolumn{2}{|c|}{ density } & \multirow{2}{*}{$\begin{array}{c}\text { permeability } \\
\text { (darcy) }\end{array}$} & \multirow{2}{*}{$\begin{array}{c}\text { diffusion } \\
\text { factor }\end{array}$} \\
\hline ID & description & $\left(\mathrm{g} / \mathrm{cm}^{3}\right)$ & (fraction) & & \\
\hline $\mathrm{Ni} 45-40$ & Nicalon $0 / 45$ layup & 1.02 & 0.40 & 11.6 & .031 \\
\hline Ni45-35 & Nicalon $0 / 45$ layup & 0.90 & 0.35 & 15.7 & nd \\
\hline Ni45-29 & Nicalon $0 / 45$ layup & 0.77 & 0.29 & 29.8 & .087 \\
\hline $\mathrm{Ni} 90-40$ & Nicalon $0 / 90$ layup & 1.02 & 0.40 & 12.4 & .045 \\
\hline Ni90-35 & Nicalon $0 / 90$ layup & 0.90 & 0.35 & 18.2 & nd \\
\hline Ni90-29 & Nicalon $0 / 90$ layup & 0.77 & 0.29 & 39.2 & .078 \\
\hline $\mathrm{Ni} 30-40$ & Nicalon $0 / 30 / 60$ & 1.02 & 0.40 & 12.6 & .048 \\
\hline $\mathrm{Ni} 30-35$ & Nicalon $0 / 30 / 60$ & 0.90 & 0.35 & 18.4 & nd \\
\hline $\mathrm{Ni30-29}$ & Nicalon $0 / 30 / 60$ & 0.77 & 0.29 & 47.4 & .095 \\
\hline C885-1 & CVI Nic $0 / 30 / 60$ & 1.89 & 0.65 & 1.86 & .0026 \\
\hline C885-2 & CVI Nic 0/30/60 & 1.93 & 0.67 & 1.30 & .0053 \\
\hline C885-3 & CVI Nic $0 / 30 / 60$ & 1.89 & 0.65 & 1.70 & .0026 \\
\hline C889-1 & CVI Nic $0 / 30 / 60$ & 1.94 & 0.67 & 5.08 & .011 \\
\hline $\mathrm{C} 889-2$ & CVI Nic $0 / 30 / 60$ & 1.98 & 0.68 & 2.97 & .024 \\
\hline C889-3 & CVI Nic $0 / 30 / 60$ & 1.92 & 0.66 & 3.14 & nd \\
\hline $\mathrm{C} 227$ & CVI Nic $0 / 30 / 60$ & 2.49 & 0.85 & $\begin{array}{l}.078 \\
.008^{1} \\
\end{array}$ & $\begin{array}{l}\text { nd } \\
\text { nd }\end{array}$ \\
\hline $\mathrm{C} 227 \mathrm{a}$ & CVI Nic $0 / 30 / 60$ & 1.96 & 0.68 & 2.20 & .002 \\
\hline $\mathrm{C} 227 \mathrm{c}$ & CVI Nic $0 / 30 / 60$ & 2.52 & 0.87 & $\begin{array}{l}2.63 \\
2.55^{1}\end{array}$ & $\begin{array}{c}.023 \\
\text { nd }\end{array}$ \\
\hline
\end{tabular}

1 darcy $=10^{-8} \mathrm{~cm}^{2} ;$ nd $=$ not determined; $(0)=$ no flow detected through specimen ${ }^{1}$ permeability remeasured with remounted specimen 


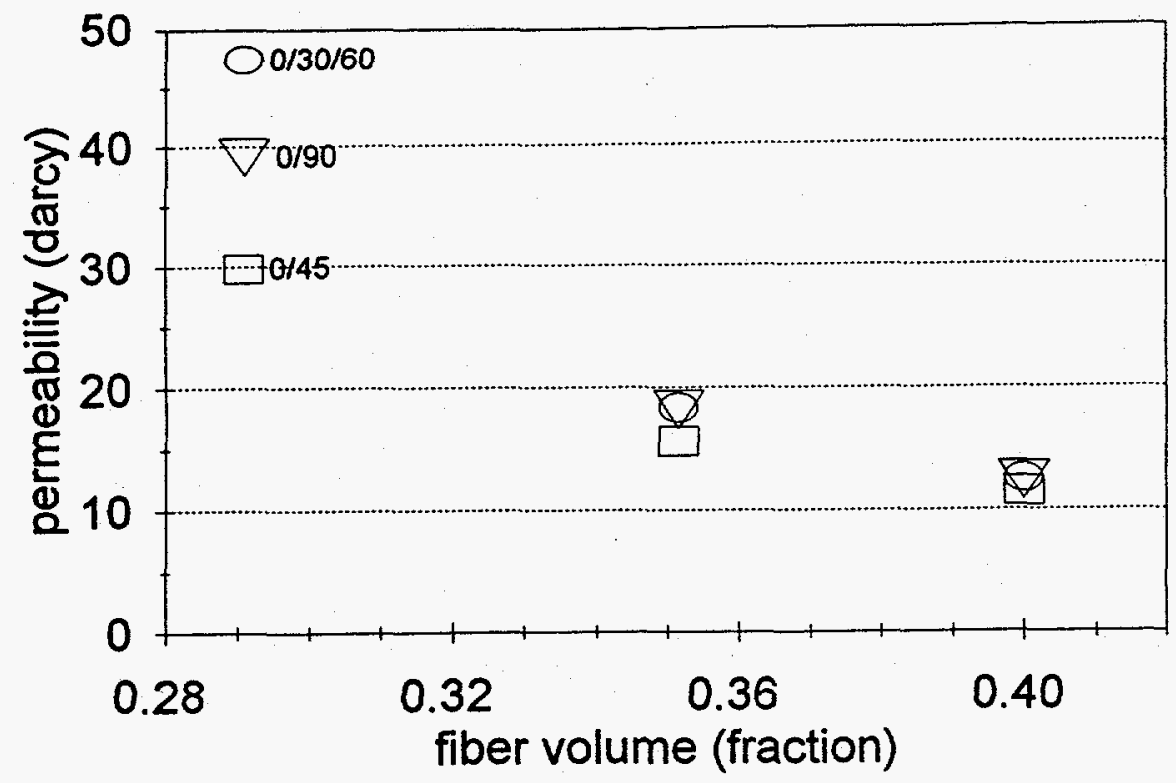

Figure 5. Permeability of Nicalon cloth layup preform depends on packing density. Orientation dependence is not significant relative to the variability between replicate specimens $(+/-20 \%)$.

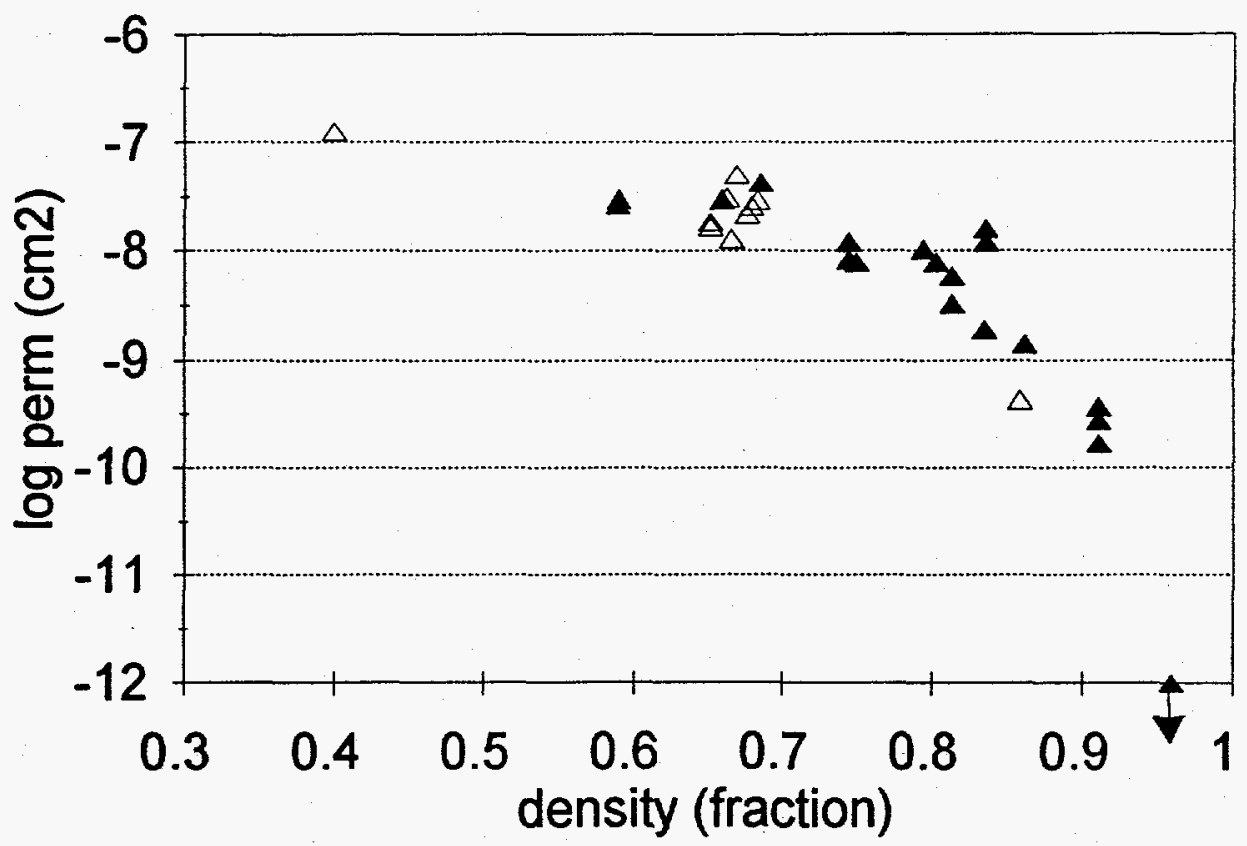

Figure 6. Gas permeability of Nicalon cloth layup preform and composites with 0/30/60 layup and $40 \%$ fiber. Open triangles are results from this report. Other values are from reference 2 . 
Table 2. Measurements of permeability and mass diffusivity for Nextel fiber braid preforms and composites.

\begin{tabular}{|c|c|c|c|c|c|}
\hline \multicolumn{2}{|r|}{ specimen } & \multicolumn{2}{|c|}{ density } & \multirow{2}{*}{$\begin{array}{c}\text { permeability } \\
\text { (darcy) }\end{array}$} & \multirow{2}{*}{$\begin{array}{c}\text { diffusion } \\
\text { factor }\end{array}$} \\
\hline ID & description & $\left(\mathrm{g} / \mathrm{cm}^{3}\right)$ & (fraction) & & \\
\hline Nex9-1 & Nextel 9 tows/inch & 0.99 & 0.37 & 25.0 & .056 \\
\hline Nex9-2 & Nextel 9 tows/inch & 0.89 & 0.33 & 17.7 & .063 \\
\hline Nex9-3 & Nextel 9 tows/inch & 1.02 & 0.38 & 18.1 & nd \\
\hline Nex12-1 & Nextel 12 tows/inch & 1.11 & 0.41 & 15.3 & .064 \\
\hline Nex12-2 & Nextel 12 tows/inch & 1.11 & 0.41 & 15.2 & .080 \\
\hline Nex16-1 & Nextel 16 tows/inch & 1.05 & 0.39 & 6.2 & nd \\
\hline C3M-1 & CVI Nextel braid & 2.38 & 0.79 & $(0)$ & $(0)$ \\
\hline C968-1 & CVI Nextel layup & 2.71 & 0.90 & $(0)$ & $(0)$ \\
\hline C969-1 & CVI Nextel layup & 1.88 & 0.63 & 7.22 & .008 \\
\hline
\end{tabular}

1 darcy $=10^{-8} \mathrm{~cm}^{2} ;$ nd $=$ not determined; $(0)=$ no flow detected through specimen

Nextel Fiber Braid Composites.

Nextel fiber (3M Company, St. Paul, MN) is currently being used to fabricate hot gas filters $^{6}$ and dense tubes ${ }^{7}$ using CVI. These preforms are fabricated using multiple layers of $3 \mathrm{M}^{\prime} \mathrm{s}$ braided sleeve which is available in various diameters and tow spacings (picks per inch). Materials tested include 1" sleeve with approximately 16 tows/inch, 1-1/2" sleeve with 12 tows/inch and 3" sleeve with 9 tows/inch. Based on 3M Company product literature Nextel 312 yarns are combinations of primary tows containing 390 filaments of 10-12 $\mu \mathrm{m}$ diameter fibers. Based on the measured cloth areal weight the three braids appear to contain yarns formed from 6,9 and 12 tows respectively. Close examination of this material shows that the yarn pattern is essentially a "twill" weave with each tow passing alternately over and under two crossing tows. Specimens of these preforms were prepared by cutting and flattening samples of the three sleeve materials, and cutting and stacking disks of this cloth in the aluminum rings, similar to the Nicalon preforms. Results for these preform specimens are shown in Table 2. 
Three additional specimens were cut from CVI densified composites infiltrated at ORNL. The specimen C3M-1 was prepared from stacked layers of Nextel braid, similar to that described above but with approximately 18 tows/inch. The C968 and C969 specimens were fabricated from plain weave cloth layup preforms of Nextel fiber. Although the thread count for this cloth was also approximately 18 tows/inch, the individual tows appeared to be smaller and the cloth appeared "looser" with more space between tows than with the braided material. These results also are shown in Table 2.

\section{Nicalon 3-D Weave Composites}

Nicalon 3-D weave preform has been evaluated at ORNL for CVI infiltration. Our attempts to prepare a permeability specimen from a piece of this preform were unsuccessful. The small specimens simply fell apart during mounting. A limited number of densified composite specimens were fabricated and tested. These results are shown in Table 3.

Table 3. Measurements of permeability and mass diffusivity for Nicalon 3-D weave composites.

\begin{tabular}{|c|c|c|c|c|c|}
\hline \multicolumn{2}{|r|}{ specimen } & \multicolumn{2}{|c|}{ density } & \multirow{2}{*}{$\begin{array}{c}\text { permeability } \\
\text { (darcy) }\end{array}$} & \multirow{2}{*}{$\begin{array}{c}\text { diffusion } \\
\text { factor }\end{array}$} \\
\hline ID & description & $\left(\mathrm{g} / \mathrm{cm}^{3}\right)$ & (fraction) & & \\
\hline C449-1 & CVI Nic 3-D weave & 2.30 & 0.79 & .098 & nd \\
\hline C449-2 & CVI Nic 3-D weave & 2.39 & 0.82 & .028 & nd \\
\hline C449-3 & CVI Nic 3-D weave & 2.57 & 0.89 & 0.11 & nd \\
\hline C449-4 & CVI Nic 3-D weave & 2.49 & 0.86 & 0.11 & nd \\
\hline C559g & CVI Nic 3-D weave & 2.04 & 0.70 & 0.50 & .0094 \\
\hline C559-1 & CVI Nic 3-D weave & 2.29 & 0.79 & $(0)$ & nd \\
\hline C559-3 & CVI Nic 3-D weave & 2.23 & 0.77 & $(0)$ & nd \\
\hline
\end{tabular}

1 darcy $=10^{-8} \mathrm{~cm}^{2} ;$ nd $=$ not determined; $(0)=$ no flow detected through specimen 


\section{DISCUSSION}

The gas permeability and diffusion factor measurement techniques described above appear to give reproducible, accurate results for gas transport in CVI preforms and composites over a range of densities. Several unique features of the method ensure this accuracy. The mounting method and specimen chamber allow one to test each specimen to ensure that gas flows only through the specimen and does not leak around the periphery or through the o-ring seals. High and low range mass flowmeters and pressure gauges allow measurements over a wide range of permeability values. And finally, the mounting method can accomodate a range of specimen sizes and geometries.

The choice of specimen size deserves further discussion. While the layup preform specimens have a volume of $2.5 \mathrm{~cm}^{3}$, most of the composite specimens are only $0.2-1.0 \mathrm{~cm}^{3}$ in size. For 40 vol\% Nicalon fiber using plain weave cloth at 16 tows/inch, the "unit cell" volume is approximately $7 \times 10^{-4} \mathrm{~cm}^{3}$. Thus, the smaller specimens contain only a few hundred unit cells of the composite. Statistically, this is a small sample for a structure with the variability inherent in woven materials and the specimen-to-specimen variation in permeability results reflects this. Choice of a larger specimen size could reduce this variability by providing a measurement that is "averaged" over a larger number of cells. On the other hand, multiple measurements with smaller specimens gives a direct measure of the variability. This additional information is useful in that it relates to structural and density variations in the final composite, and ultimately to the performance of the material.

The gas permeability and diffusion factor results shown here are the most extensive measurements reported for CVI preforms and partially densified composites. While the number of measurements for the Nextel braid and for the Nicalon 3-D weave are small, results for Nicalon cloth layup span the full range of density from preform to dense composite.

While the permeability of these composites certainly decreases with increasing density (Figure 6), the variability of this property increases. At high density, two specimens of comparable density can have permeabilities that differ by orders of magnitude. This is seen clearly in Table 1 for specimens C227 and C227c. Both specimens were cut from the same composite disk and have comparable densities, but their gas permeabilities differ by a factor of approximately 250 . This phenomenon is characteristic of a "percolating" network ${ }^{8}$. As density increases the number of continuous channels between opposite faces of the specimen becomes 
very small. The permeability depends on the number and unique geometry of these few channels which can be very different for a randomly positioned cloth layup. How the characteristics of this percolating network depend on the weave or braid process likely is a key element in developing a predictive model of gas transport.

A number of composite specimens from this and previous ${ }^{2}$ work were found to be impermeable, even though the larger disk from which they were extracted had a finite permeability. (The "end" of the forced CVI process is chosen as the point at which the backpressure needed to maintain the desired flow rises to a selected value. For typical ORNL disk infiltration conditions the composite would have a permeability of 0.08 darcy at "full" density, assuming that all flow passes through the disk.) While this result is not unexpected in light of the discussion in the preceding paragraph, it raises additional processing-related questions. How is it that a process that relies on gas flow produces gas impermeable material?

For a given volume of material there are two possiblities. First, the composite is permeable in a direction different than that defined by the specimen mounting, e.g. parallel to the cloth layers. In this case we envision, near the end of the CVI process, that the gas flows transverse to the overall pressure gradient for some distance within the composite before encountering an open channel allowing flow to advance further through the material. Densification in this case involves diffusion across the microscopic flow path and deposition onto nearby open pore surfaces. A second possibility is that the volume of material contains no continuous channel connecting any two faces of the specimen. In this case any gas transport and continued densification in the interior of the volume would involve diffusion over some distance. Overall, it is likely that both of these transport mechanisms occur to some extent within the composite as density increases and that "forced-flow" CVI densification involves a significant amount of "diffusion" near the end of the process.

Greater understanding of mass transport near the end of the densification process has great practical importance. Some applications of ceramic matrix composites, such as high temperature heat exchangers, require that the material be gas tight. Also, resistance of the material to oxidation or corrosion by atmospheric gases can be enhanced by eliminating porosity open to the surface. These measurements indicate that forced-flow CVI does produce finite size regions of impermeable material. Methods to enhance this result by control of the preform architecture or by modification of the process will rely on improved understanding of transport phenomena. 


\section{CONCLUSIONS}

Experimental methods for reliable measurement of gas pemeability and diffusion in fiber preforms and CVI densified composites have been developed. Key characteristics of this method are use of relatively small specimens and implementation of methods to ensure through-specimen transport. Multiple measurements with small specimens provide information about material variability in addition to the average value of the transport properties. Nicalon plain weave cloth layup composites have been characterized over a wide range of density. Additional measurements are needed for other fibers and fiber architectures in order to gain a full understanding of structure-transport relationships.

\section{ACKNOWLEDGEMENT}

This research is sponsored by the U.S. Department of Energy, Fossil Energy Advanced Research and Technology Development Materials Program.

\section{REFERENCES}

1. J. Pich, "Gas Filtration Theory," in Filtration: Principles and Practices C. Orr, ed. (M. Dekker, New York, NY:1987) pp. 2-153

2. G.B. Freeman, T.L. Starr and T.C. Elston, "Transport properties of CVI preforms and composites," Mat. Res. Soc. Proc. $\underline{168} 49-54$ (1990)

3. T.L. Starr, "Gas transport model for chemical vapor infiltration," J. Mater. Res. 10(9) 23602366 (1995)

4. CRC Handbook of Chemistry and Physics, 68th edition R.C. West, ed. (CRC Press, Boca Raton, FL: 1987)

5. R.G. Smith, J.H. Eaton D.J. Pysher and M. A. Leitheiser, "Fabrication of Full-Scale Fiber Reinforced Hot Gas Filters by Chemical Vapor Deposition," Final Report ORNL/Sub/89Sb482C/04 by 3M Company for Oak Ridge National Laboratory, January 1996

6. T.L. Starr, D.Y. Chiang, T.M. Besmann, D.P. Stinton, J.C. McLaughlin and W.M. Matlin, "Rapid fabrication of ceramic composite tubes using chemical vapor infiltration," Ceramic Transactions, accepted for publication (1996)

7. D. Stauffer and A. Aharony, Introduction to Percolation Theory (Taylor and Francis, Washington, DC: 1992) 
APPENDIX:

DISTRIBUTION 
3M COMPANY

Ceramic Materials Department 201-4N-01 3M Center,

St. Paul, MN 55144

M. A. Leitheiser

AIR PRODUCTS AND CHEMICALS

P.O. Box 538

Alientown, PA 18105

S. W. Dean

ALLISON GAS TURBINE DIVISION

P.O. Box 420

Indianapolis, IN 46206-0420

P. Khandelwal (Speed Code W-5)

R. A. Wenglarz (Speed Code W-16)

AMA RESEARCH \& DEVELOPMENT CENTER 5950 McIntyre Street

Golden, CO 80403

T. B. Cox

ARGONNE NATIONAL LABORATORY

9700 S. Cass Avenue

Argonne, IL 60439

W. A. Ellingson

J. P. Singh

ARGONNE NATIONAL LABORATORY-WEST

P.O. Box 2528

Idaho Falls, ID 83403-2528

S. P. Henslee

BABCOCK \& WLCOX

Domestic Fossil Operations

20 South Van Buren Avenue

Barberton, $\mathrm{OH} 44023$

ivi. Goid

BRITISH COAL CORPORATION

Coal Technology Development Division

Stoke Orchard, Cheltenham

Glocestershire, England GL52 4ZG

J. Oakey
CANADA CENTER FOR MINERAL \& ENERGY

TECHNOLOGY

568 Booth Street

Ottawa, Ontario

Canada K1A OG1

R. Winston Revic

Mahi Sahoo

DOE

DOE OAK RIDGE OPERATIONS

P.O.Box 2001

Oak Ridge, TN 37831

Assistant Manager for

Energy Research and Development

DOE

DOE OAK RIDGE OPERATIONS

P. O. Box 2008

Building 4500N, MS 6269

Oak Ridge, TN 37831

M. H. Rawlins

DOE

OFFICE OF BASIC ENERGY SCIENCES

Materials Sciences Division

ER-131

19901 Germantown Road

Germantown, MD 20874-1290

H. M. Kerch

DOE

IDAHO OPERATIONS OFFICE

P. O. Box 1625

Idaho Falls, ID 83415

J. B. Malmo

DOE

MORGANTOWN ENERGY TECHNOLOGY

CENTER

P.O. Box 880

Morgantown, WW 26505

R. C. Bedick

D. C. Cicero

F. W. Crouse, Jr.

R. A. Dennis

N. T. Holcombe

W. J. Huber

T. J. McMahon

J. E. Notestein 


\section{DOE}

OFFICE OF FOSSIL ENERGY

FE-72

19901 Germantown Road

Germantown, MD 20874-1290

J. P. Carr

\section{DOE}

OFFICE OF VEHICLE AND ENERGY R\&D

CE-151 Forrestal Building

Washington, DC 20585

R. B. Schulz

\section{DOE}

PITTSBURGH ENERGY TECHNOLOGY

CENTER

P.O. Box 10940

Pittsburgh, PA 15236

A. L. Baldwin

G. V. McGurl

L. A. Ruth

T. M. Torkos

DOW CORNING CORPORATION

3901 S. Saginaw Road

Midland, Mi 48686-0995

H. Atwell

EC TECHNOLOGIES

3614 Highpoint Drive

San Antonio, TX 78217

D. J. Kenton

ELECTRIC POWER RESEARCH INSTITUTE P.O. Box 10412

3412 Hillview Avenue

Palo Alto, CA 94303

W. T. Bakker

J. Stringer

EUROPEAN COMMUNITIES JOINT

RESEARCH CENTRE

Petten Establishment

P.O. Box 2

1755 ZG Petten

The Netherlands

$M$. Van de Voorde

GA TECHNOLOGIES. INC.

P.O. Box 85608

San Diego, CA 92138

T. D. Gulden
GEORGIA INSTITUTE OF TECHNOLOGY

Materials Science \& Engineering (0245)

Bunger-Henry Building, Room 276

Atlanta, GA 30332-0245

T. L. Starr

IDAHO NATIONAL ENGINEERING

LABORATORY

P. O. Box 1625

Idaho Falls, ID 83415

B. H. Rabin

LAVA CRUCIBLE-REFRACTORIES CO.

P.O. 5O× 278

Zelienople, PA 16063

T. Mulholland

LAWRENCE LIVERMORE NATIONAL LABORATORY

P.O. Box 808, L-325

Livermore, CA 94550

W. A. Steele

LOS ALAMOS NATIONAL LABORATORY

P.O. Box 1663

Los Alamos, NM 87545

J. D. Katz

NATIONAL MATERIALS ADVISORY BOARD

National Research Council

2101 Constitution Avenue

Washington, DC 20418

K. M. Zwilsky

OAK RIDGE NATIONAL LABORATORY

P.O. BOX 2008

Oak Ridge, TN 37831

P. T. Carlson

N. C. Cole

F. D. Johnson (5 copies)

R. R. Judkins

E. L. Long, Jr.

D. P. Stinton

M. R. Upton

OFFICE OF NAVAL RESEARCH Code 431,800 N. Quincy Street Arlington, VA 22217

S. G. Fishman 
SANDIA NATIONAL LABORATORIES Department 6211, MS 0710

Albuquerque, NM 87185

R. J. Buss

G. A. Carison

A. G. Sault

SHELL DEVELOPMENT COMPANY

P.O. Box 1380

Houston, TX 77251-1380

L. W. R. Dicks

YENYISSFEE VILLEV AUTHORITY

Energy Demonstration \& Technology MR2N58A

Chattanooga, TN 37402-2801

C. M. Huang

THE JOHNS HOPKINS UNIVERSITY Materials Science \& Engineering Maryland Hall

Baltimore, MD 21218

R. E. Green, Jr.

THE MATERIALS PROPERTIES COUNCIL, INC.

United Engineering Center

345 E. Forty-Seventh Street

New York, NY 10017

M. Prager

THE NORTON COMPANY

High Performance Ceramics Division

Goddard Road

Northborough, MA 01532-1545

N. Corbin

THE TORERINGTON COMPANY

Advanced Technology Center

59 Field St.

Torrington, CT 06790

W. J. Chmura

\section{UNION CARBIDE CORPORATION}

Linde Division

P.O. Box 44

175 East Park Drive

Tonawanda, NY 14151-0044

Harry Cheung
UNITED TECHNOLOGIES RESEARCH

CENTER

MS 24, Silver Lane

East Hartford, CT 06108

K. M. Prewo

UNIVERSITY OF TENNESSEE

Dept of Materials Science and Engineering

Knoxville, TN 37996-2200

Peter Liaw

UNIVERSITY OF WASHINGTON

Depar'ment of M!zterials Science and

Engineering

101 Wilson, FB-10

Seattle, WA 98195

T. G. Stoebe

VIRGINIA POLYTECHNIC INSTITUTE \&

STATE UNIVERSITY

Department of Materials Engineering

Blackburg, VA 24601

W. A. Curtin

K. L. Reifsnider

WESTERN RESEARCH INSTITUTE

365 N. 9th Street

P.O. Box 3395

University Station

Laramie, WY 82071

V. K. Sethi

\author{
WESTINGHOUSE ELECTRIC CORPORATION \\ Research and Development Center \\ 1310 Beulah Road \\ Pittsburgh, PA 15235 \\ S. C. Singhal
}

